\title{
HAEMOSTASIS MODULATION BY CALIX[4]ARENE METHYLENEBISPHOSPHONIC ACID C-145 AND ITS SULFUR-CONTAINING ANALOGUE
}

\author{
V. O. CHERNYSHENKO ${ }^{1 凶}$, O. V. SAVCHUK ${ }^{1}$, S. O. CHERENOK ${ }^{2}$, \\ O. M. SILENKO ${ }^{2}$, A. O. NEGELIA ${ }^{3}$, L. O. KASATKINA ${ }^{1}$, L. V. PIROGOVA 1 , \\ V. A. DIDKIVSKYI , O. I. YUSOVA ${ }^{1}$, V. I. KALCHENKO ${ }^{2}$, L. V. GARMANCHUK ${ }^{3}$, \\ T. V. GRINENKO ${ }^{1}$, E. V. LUGOVSKOY', S. V. KOMISARENKO ${ }^{1}$ \\ ${ }^{1}$ Palladin Institute of Biochemistry, National Academy of Sciences of Ukraine, Kyiv; \\ ${ }^{2}$ Institute of Organic Chemistry, National Academy of Sciences of Ukraine, Kyiv; \\ ${ }^{3}$ ESC Institute of Biology and Medicine, \\ Taras Shevchenko National University of Kyiv, Ukraine; \\ ${ }^{\square}$-mail: bio.cherv@gmail.com
}

C-145 (octasodium salt of calix[4]arene-tetra-methylenebisphosphonic acid) was previously considered as specific anti-coagulant agent that affects fibrin polymerization and does not notably influence other parameters of coagulation system. C-145S (octasodium salt of thiacalix[4]arene-tetra-methylenebisphosphonic acid) possessing wider hydrophobic hole was expected to be more effective antithrombotic agent than $C$-145. The aim of present work was to compare the action of both organic compounds on fibrin polymerization, fibrinolysis, platelets and endothelial cells. The change of turbidity during fibrin clot formation induced by APTT-reagent and digestion induced by tPA was estimated. Turbidity study was used for the estimation of polymeric fibrin hydrolysis by plasmin in the presence of thiacalix[4]arene C-145S and calix[4]arene C-145. Effects of thiacalix[4]arene C-145S and calix[4]arene C-145 on the activation of Glu-plasminogen by streptokinase were studied using chromogenic substrate S2251. Platelet aggregation study was performed using aggregometry. Stimulated $\mathrm{Ca}^{2+}$ efflux from endoplasmic reticulum and cytoplasm were determined using specific $\mathrm{Ca}^{2+}$-sensitive probes targeted to endoplasmic reticulum (Mag-Fluo-4) and cytoplasm (FURA-2) by spectrofluorimetry. Both C-145 and C-145S decreased the final turbidity of clot and prolonged clot lysis time in blood plasma in comparison to control value. C-145 was shown to be the more effective fibrinolysis inhibitor when studied in model system of polymerized fibrin desAB. C-145S but not C-145 induced concentration changes of $\mathrm{Ca}^{2+}$ in cytoplasm of resting platelets and significantly inhibited (up to 30\%) $\mathrm{Ca}^{2+}$ efflux from endoplasmic reticulum of platelets activated by ADP. Both C-145 and C-145S stimulated the proliferation of endothelial cells of PAE cell line. The effect of C-145S was more prominent. In conclusion, calix[4]arene C-145S proved to be the more potent inhibitor of fibrin polymerization in comparison to C-145, which suggested earlier as anticoagulant agent. $C$-145S proved to have much more outlined inhibitory action on $\mathrm{Ca}^{2+}$-signaling in platelets and stimulatory effect on endothelial cells proliferation. Thus C-145 remained the most prospective molecular platform for the development of antithrombotic agent.

Keywords: calix[4]arene, haemostasis, fibrinolysis, endothelial cells, platelets, blood coagulation, antithrombotic drugs.

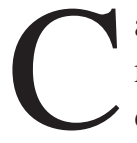
alix[4]arenes and thiacalix[4]arenes are macrocyclic compounds composed of hydrophobic 'cup' that is modified on the edge by fragments of methylenebisphosphonic acid [1]. They can effectively bind amino acids, namely Ar- ginine and Arginine-containing peptides as well as proteins and supramolecular complexes in solution $[2,3]$. Non-surprisingly that calix[4]arenes and their derivatives found application as inhibitors of various biochemical processes $[4,5]$.

(C) 2018 Chernyshenko V. O. et al. This is an open-access article distributed under the terms of the Creative Commons Attribution License, which permits unrestricted use, distribution, and reproduction in any medium, provided the original author and source are credited. 
It was previously shown that calix[4]arene C-192 and its Sodium salt C-145 effectively inhibited the polymerization of fibrin by direct blocking of A:a knob-hole interactions during its polymerization thus preventing the formation of three-dimensional fibrin network that is the core of thrombus [6]. Such unique properties allowed us to assume the possible use of C-145 in antithrombotic therapy. Further results concerning C-145 influence on the other blood proteins were extremely promising. C-145 did not influence any of the studied haemostatic compounds even being injected in vivo into rabbit's bloodstream [7]. However several other unexpected effects of C-145 were found. First of all, in vivo administration of C-145 leaded to huge decrease of platelets concentration that was however restored after 24 hours. Also C-145 effectively induces proliferation of endothelial cells in cell culture $[8,9]$. These properties were alarming in the light of biomedical application of C-145. Anti-platelet action increases the overall anticoagulant action of C-145, and stimulation of endothelial cells proliferation is promising for the increasing of revascularization of tissues wounded by ischemia. Some inhibitory action of C-145 on fibrinolysis that did not impair anticoagulant action in vivo was also detected [10].

To implement calix[4]arenes as the molecular platform for the development of antithrombotic drugs we have to study all mentioned effects more precisely. We also aimed to find calix[4]arene that would possess anticoagulant action similar to C-145 and would not have side-effects.
Data of computer modeling demonstrated that thiacalix[4]arenes and in particular C-145S have bigger hydrophobic 'cup' then C-145 described previously (Fig. 1). It contains four atoms of Sulfur that unite heterocyclic compounds and that is why is more flexible and could have higher specificity to protein substrate. So we assumed that C-145S also can be more specific to fibrin and possess less of nonspecific effects that we assumed are anti-platelet and anti-fibrinolytic actions.

In this work we aimed to test this suggestion by head-to-head comparison of C-145 and C-145S action on fibrin polymerization, fibrin digestion and platelet reactivity.

\section{Materials and Methods}

Materials. Calix[4]arene C-145 and thiacalix[4]arene C-145S preparation. Calix[4]arene C-145 was obtained according to method described in [8]. Thiacalix[4]arene C-145S was obtained by the same procedure but as the starting compound for synthesis was used tetraformyl thiacalix[4]arene.

Chemicals. HEPES, APTT-reagent, tissue type plasminogen activator (t-PA) DMEM, MTT 3-(4,5-Dimethylthiazol-2-yl)-2,5-Diphenyltetrazolium Bromide, dimethyl sulfoxide were purchased from Sigma (USA). ADP was from Merck (Germany). $\mathrm{Ca}^{2+}$-sensitive probes targeted to endoplasmic reticulum (Mag-Fluo-4) and cytoplasm (Fura-2) were purchased by ThermoFisher Scientific (USA). Chromogenic substrate of plasmin S2251 (H-D-ValL-Ley-L-Lys-p-nitroaniline hydrochloride was from
$A$

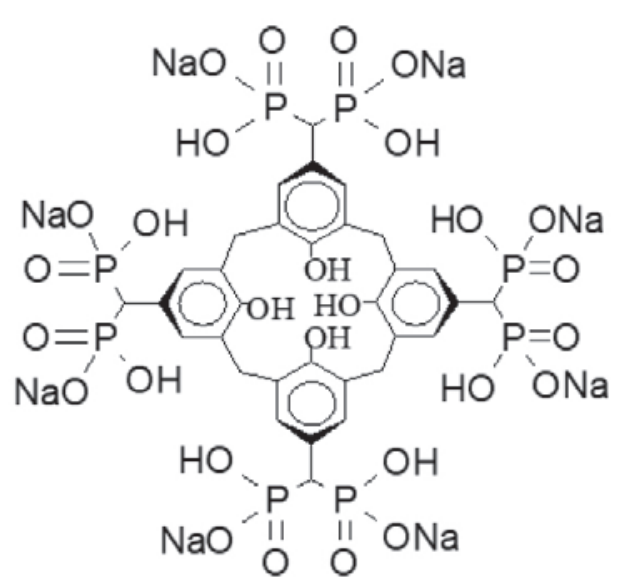

$B$

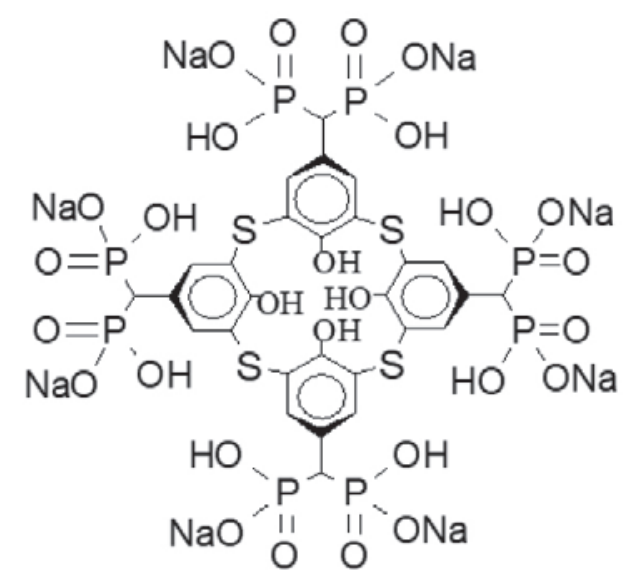

Fig. 1. Structures of C-145 (octasodium salt of calix[4]arene-tetra-methylenebisphosphonic acid) and C-145S (octasodium salt of thiacalix[4]arene-tetra-methylenebisphosphonic acid) 
Renam (Russia), streptokinase from Belmedpreparat (Belorussia). Cell line PAE was a kind gift of Prof. I. T. Goot (University of London).

Methods. Blood sampling and blood plasma obtaining. Human blood samples were obtained from healthy donors. Volunteers signed informed consent prior to blood sampling according to the Helsinki declaration. 3.8\% Sodium citrate added immediately after collection to whole blood in 1:9 ratio was used as an anticoagulant. Platelet rich plasma (PRP) was obtained from human citrated blood by centrifugation at $1500 \mathrm{rpm}$ during $30 \mathrm{~min}$. For preparation of platelet poor plasma PRP was additionally spinned-down at $1500 \mathrm{rpm}$ during $30 \mathrm{~min}$.

Overall haemostatic potential. For estimation of blood plasma haemostatic potential the change of turbidity during clot formation induced by APTT-reagent was estimated. The clots were formed in wells of microplate, to which the following reagents were added sequentially: 0.05 M HEPES buffer ( $\mathrm{pH}$ 7.4), containing $0.15 \mathrm{M} \mathrm{NaCl}, 70 \mu \mathrm{l}$ blood plasma, and $4 \mu \mathrm{l}$ of APTT reagent. The plasma clotting was initiated by adding of $25 \mathrm{mM} \mathrm{CaCl}{ }_{2}$. The final reaction volume was $300 \mu 1$ [11]. In alternative probes tissue type plasminogen activator (t-PA) was added to a final concentration of $75 \mathrm{IU} / \mathrm{ml}$. The change of turbidity during the formation and degradation of fibrin clot were monitored constantly at $405 \mathrm{~nm}$ using Multiskan EX (Thermo Fisher Scientific, Finland).

Basic coagulation parameters were calculated using experimental curves. The area under the curve of turbidity was used to quantify overall haemostatic potential (OHP). Coagulation potential $(\mathrm{CP})$ was estimated as the area under the curve of clot formation, obtained without tPA, from the initiation of blood plasma coagulation until a moment of the complete clot degradation that was formed in the presence of t-PA. All values were expressed in units of absorbance multiplied by the time in seconds (a.u. $\times$ s) [12]. Areas under the curves were calculated by integration of the values of turbidity in each checkpoint [13].

Half-time of clot lysis was calculated as period of time from the beginning of clot formation to the point when the turbidity of clot was $1 / 2$ from the maximal density.

Hydrolysis of polymeric fibrin by plasmin. Turbidity study was used for the estimation of polymeric fibrin hydrolysis by plasmin in the presence of thiacalix[4] arene C-145S and calix[4]arene C-145. The study volume was mixed in the thermostatic tube of spectrophotometer SF-26, Lomo (USSR).
It contained $0.02 \mathrm{M}$ veronal buffer $\mathrm{pH} 7.4$ with $0.001 \mathrm{M} \mathrm{CaCl}_{2}$ and $0.13 \mathrm{M} \mathrm{NaCl} ; 3 \mu \mathrm{g}(35 \mathrm{nM})$ of plasmin, $0.15 \mu \mathrm{g}(3.2 \mu \mathrm{M})$ of streptokinase and thiacalix[4]arene C-145S and calix[4]arene C145 in the range of concentration $10-100 \mu \mathrm{M}$, control sample contained the equivalent volume of the buffer solution. The clot formation was initiated by the addition of $200 \mu \mathrm{g}(588 \mathrm{nM})$ of monomeric fibrin desAB to the incubation volume. Total volume of incubation mixture was $1 \mathrm{ml}$. Reaction was monitored at $37^{\circ} \mathrm{C}$. The process of fibrin clot formation and digestion was measured by the change of turbidity at $350 \mathrm{~nm}$. We measured the time from initial point of polymerization to the point when clot turbidity was $50 \%$ from the maximal meanings $\left(t^{1} / 2\right)$. The speed of lysis was estimated as the inverse value to $t^{1 / 2}-1 / t^{1} / 2, \mathrm{~s}^{-1}$.

Activation of Glu-plasminogen by streptokinase. Effects of thiacalix[4]arene C-145S and calix[4]arene C-145 on the activation of Glu-plasminogen by streptokinase were studied using chromogenic substrate. The activity of plasmin generated by streptokinase was estimated using achromogenic substrate of plasmin S2251 (H-D-Val-L-Ley-L-Lys$p$-nitroaniline hydrochloride, Renam, Russia). Activation volume that was mixed in the wells of 96well plate (Greiner bio-one, Germany) in $0.05 \mathrm{M}$ Tris-HCl buffer, pH 7.4 with $0.13 \mathrm{M} \mathrm{NaCl}$, at $37^{\circ} \mathrm{C}$. Total incubation volume was $0.25 \mathrm{ml}$, it contained $5 \mu \mathrm{g}(200 \mu \mathrm{M})$ of Glu-plasminogen, $0.025 \mu \mathrm{g}(2 \mu \mathrm{M})$ of streptokinase (Belmedpreparat, Belorussia), $30 \mu \mathrm{g}$ $(375 \mu \mathrm{M})$ of monomeric fibrin. Mixture also contained $1-100 \mu \mathrm{M}$ of C-145 or C-145S. Control sample contained the equivalent volume of the buffer solution. The change of optical density during p-nitroaniline generation was measured using Multiskan EX (Thermo Fisher Scientific, Finland) at the wavelength $405 \mathrm{~nm}$ (reference wavelength was $492 \mathrm{~nm}$ ).

Platelet aggregation measurement. Platelet aggregation measurements were based on changes in the turbidity of human platelet-rich plasma [14]. Aggregation was registered for 10 min using Aggregometer Solar AP2110 (Belorussia). We estimated the initial rate and final level of aggregation at $37^{\circ} \mathrm{C}$. In typical experiment $250 \mu$ of PRP was activated by $12.5 \mu \mathrm{M}$ of ADP in the presence of thiacalix[4]arene C-145S or calix[4]arene C-145. Control sample contained equivalent volume of $0.05 \mathrm{M}$ HEPES buffer (pH 7.4) with $0.15 \mathrm{M} \mathrm{NaCl}$.

Measurements of the level of $\mathrm{Ca}^{2+}$ in platelets. Stimulated changes of $\mathrm{Ca}^{2+}$ level in the presence of thiacalix[4]arene C-145S or calix[4]arene C-145 in 
platelets was registered using $\mathrm{Ca}^{2+}$-sensitive probes FURA-2/AM, retained in cytosol, or Mag-Fluo-4/ AM, targeted mainly to endoplasmic reticulum [15].

Platelets were loaded with FURA-2/AM $(1 \mu \mathrm{M})$ at $30{ }^{\circ} \mathrm{C}$ for $60 \mathrm{~min}$, washed twice and left for $30 \mathrm{~min}$ to let complete de-esterification. Suspensions of FURA-2-loaded platelets were excited alternately at 340 and $380 \mathrm{~nm}$ and fluorescence was recorded at $510 \mathrm{~nm}$ to calculate the $340 / 380$ excitation ratio. In situ calibrations were conducted in the presence of $5 \mu \mathrm{M}$ A23187. The intracellular concentration of $\mathrm{Ca}^{2+}$ (in $\mathrm{nM}$ ) was calculated according to the Grynkiewicz, Poenie and Tsien equation [16].

Mag-Fluo-4-loaded samples were excited at $480 \mathrm{~nm}$ and the signal intensity was recorded at $520 \mathrm{~nm}$. The intensities were normalized to baseline after background subtraction. Measurements were performed using the QuantaMaster 40 spectrofluorimeter (Photon Technology International, Inc., Canada).

Cell cultivation. Cell line of PAE (Porcine Aortic Endothelial Cells) was incubated in DMEM medium supplemented with $10 \%$ FBS, $2 \mathrm{mM}$ L-glutamine and $40 \mathrm{mg} / \mathrm{ml}$ gentamicin at standard conditions (at $37{ }^{\circ} \mathrm{C}$ in $5 \% \mathrm{CO}_{2}$ ) during two days. Thiacalix[4]arene C-145S and calix[4]arene C-145 in concentration range from 2.5 to $100 \mu \mathrm{M}$ in $0.05 \mathrm{M}$ Tris- $\mathrm{HCl}$ buffer, $\mathrm{pH} 7.4$ with $0.13 \mathrm{M} \mathrm{NaCl}$ were added to the culture medium. Equivalent volume of $0.05 \mathrm{M}$ tris- $\mathrm{HCl}$ buffer, $\mathrm{pH} 7.4$ with $0.13 \mathrm{M} \mathrm{NaCl}$ was added to control samples. Cell viability was measured by MTT-colorymetric test. The cell proliferation was expressed as percentage of the viable cell number of the control (non-treated cells) and calix[4]arenetreated cells [17].

Statistical data analysis was performed using Microsoft Excel. All assays were performed in series of three replicates and the data were fitted with standard errors using "Statistica 7". Results are presented as means \pm standard deviation. The difference between the groups was analyzed by one way ANOVA. Data were considered significant when $P<0.05$.

\section{Results and Discussion}

Fibrin formation and digestion in blood plasma. To study the action of C-145 and C-145S on formation and digestion of fibrin clot in blood plasma we used the method of overall haemostatic potential according to Blombäck [18]. Both studied compounds were in a form of Sodium salt and analyzed in the range of concentration from 10 to $50 \mu \mathrm{M}$.

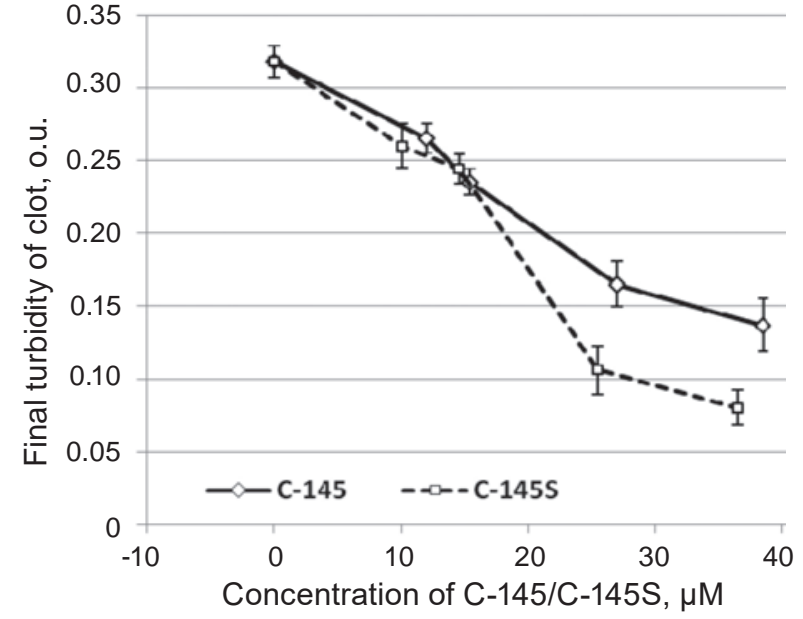

Fig. 2. Dependences of maximal turbidity of clot formed in blood plasma under the action of APTTreagent from the concentration of thiacalix[4]arene C-145S and calix[4]arene C-145

It was shown that both compounds were effective inhibitors of APTT-induced clotting of blood plasma. Thiacalix[4]arene C-145S was shown to be more effective then calix[4]arene C-145 $\left(\mathrm{IC}_{50}=20 \mu \mathrm{M}, \mathrm{IC}_{50}=27 \mu \mathrm{M}\right.$, respectively). However in a zone of low concentrations $(10-20 \mu \mathrm{M})$ that were recommended for in vivo use of C-145, the effects of both compounds were almost the same (Fig. 2).

In the same set of experiment we also compared the time of tPA-induced half-time of fibrin clot lysis in the presence of C-145 and C-145S (Fig. 3). It

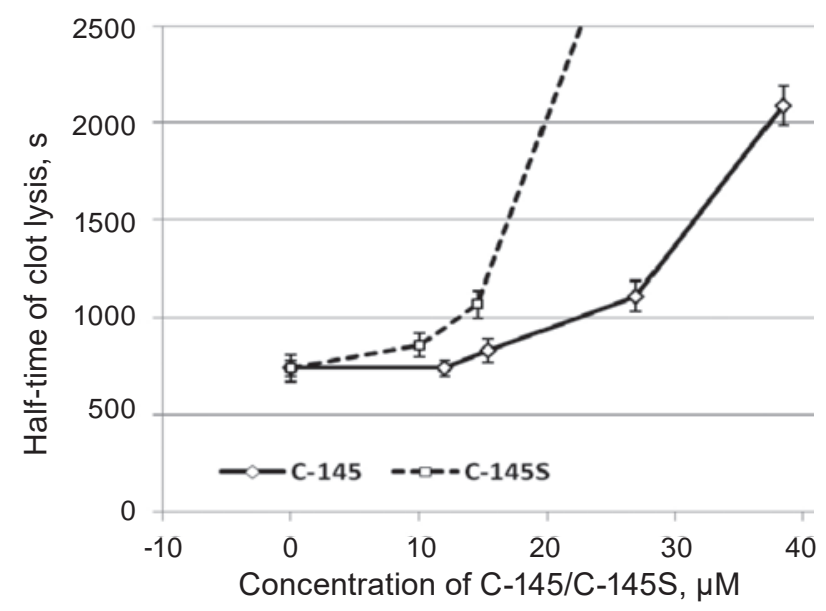

Fig. 3. Dependences of the time of half-time of tPA-induced lysis of fibrin clot formed in blood plasma under the action of APTT-reagent from the concentration of thiacalix[4]arene C-145S and calix[4]arene C-145 


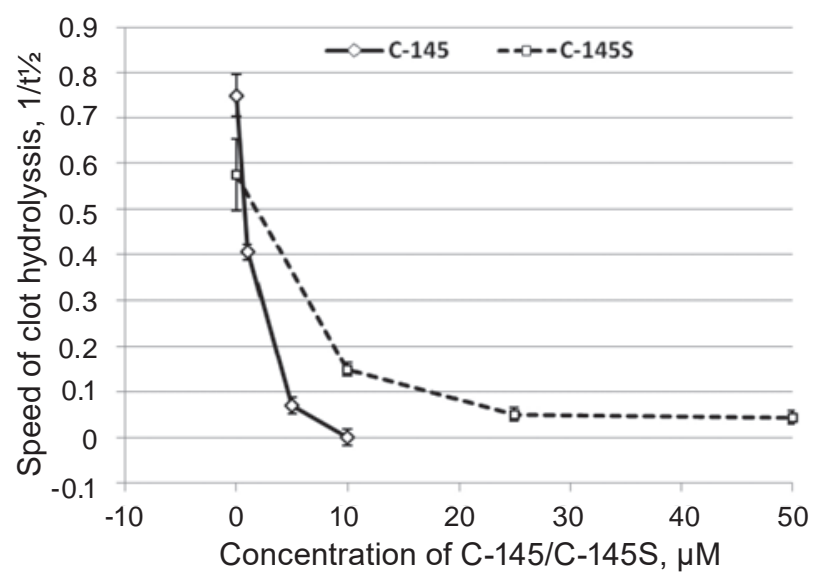

Fig. 4. Dependences of the speed of plasmin-induced lysis of fully formed fibrin desAB clot from the concentration of thiacalix[4]arene C-145S and calix[4]arene C-145

was demonstrated that C-145S effectively inhibited clot lysis and completely terminated it taken in concentrations above $35 \mu \mathrm{M}$. In the same time, C-145 effectively inhibited clot lysis only at concentration of $40 \mu \mathrm{M}$. The half-time of clot lysis was prolonged no more than in 1.5 times in the range of C-145 concentration from 10 to $27 \mu \mathrm{M}$.

Digestion of polymeric fibrin and plasminogen activation. To study the effects of C-145 and C-145S on fibrilolysis, we examinated the lysis of polymeric fibrin desAB in model system. Monomeric fibrin desAB that was dissolved in $0.125 \%$ acetic acid was immediately polymerized being added to the sample media with neutral $\mathrm{pH}$. That is why we can separate the effect of studied compounds on fibrin polymerization and study fibrinolysis more precisely.

It was shown that $\mathrm{C}-145$ taken in concentration of $10 \mu \mathrm{M}$ completely diminished the hydrolysis of fully formed fibrin desAB clot by plasmin. On the other hand, C-145S at concentration of $10 \mu \mathrm{M}$ C-145S inhibited fibrin desAB hydrolysis on $75 \%$. Complete inhibition of hydrolysis by C-145S was observed at $50 \mu \mathrm{M}$ (Fig. 4).

We observed the difference of the action of studied compounds on fibrin clot that was formed in blood plasma under the action of endogenous thrombin and the clot that was formed immediately in neutral solution from monomeric fibrin desAB [19]. It can be assumed that the structural properties of clot influence peculiarities of calix[4]arene and thiacalix[4]arene action on its lysis.

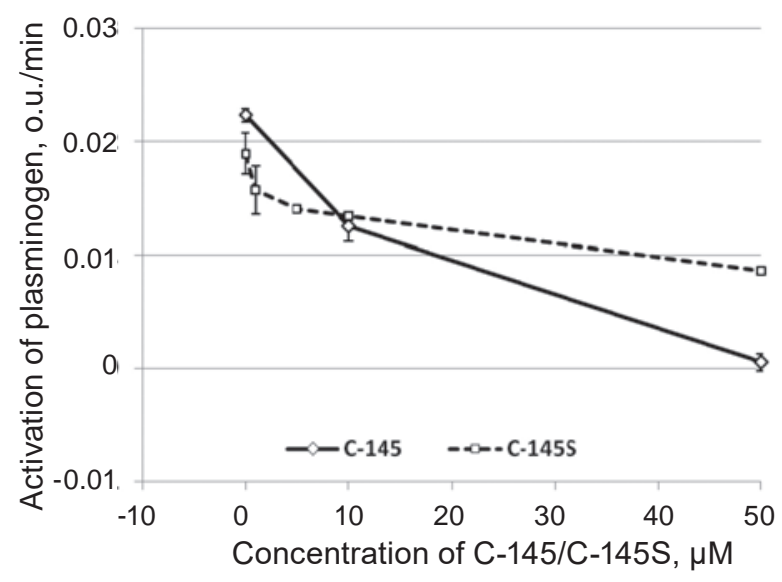

Fig. 5. Activation of plasminogen by streptokinase in the presence of thiacalix[4]arene C-145S and calix[4]arene C-145 determined using plasmin-specific chromogenic substrate S2251

Direct action of C-145 and C-145S on plasminogen activation was also observed. It was shown that the presence of $10 \mu \mathrm{M}$ of each studied compound in the incubation volume leaded to $50 \%$ diminishing of plasminogen activation. C-145 was generally more effective inhibitor of plasminogen activation than C-145S (Fig. 5).

Thus, C-145 was shown to be more effective fibrinolysis inhibitor when studied in model systems and C-145S possessed lower antifibrinolytic activity. However in blood plasma studies both compounds were effective inhibitors of fibrinolysis at high concentrations (50 $\mu \mathrm{M}$ and higher) and moderately sup-

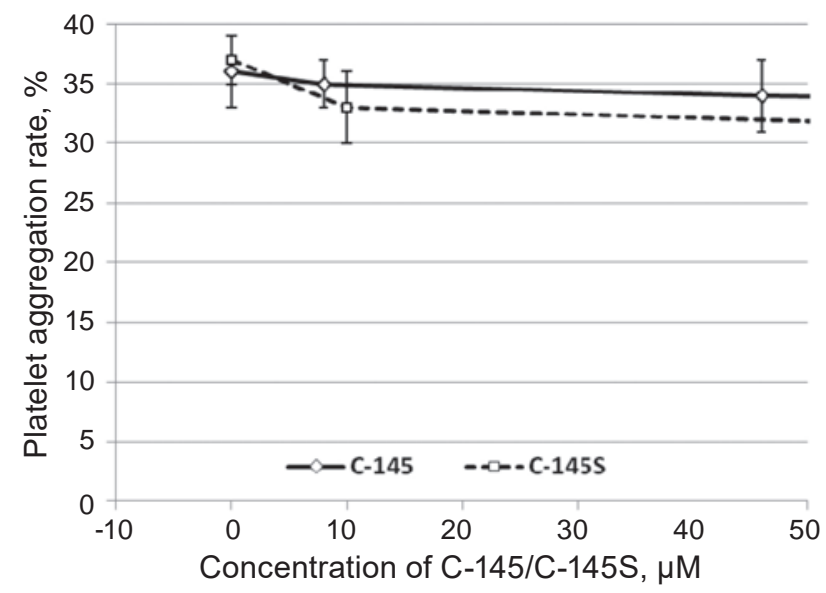

Fig. 6. Effects of different concentrations of thiacalix[4]arene C-145S and calix[4]arene C-145 on the rate of platelet aggregation induced by $12.5 \mu \mathrm{M}$ of ADP 

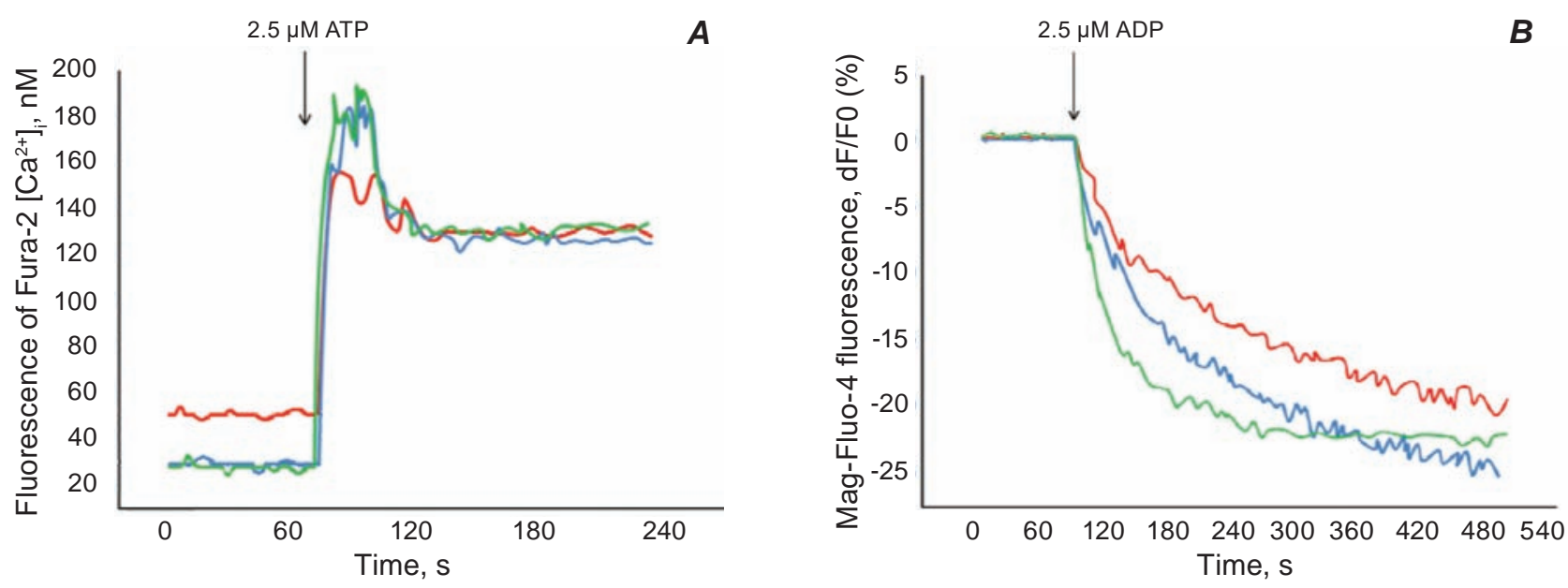

Fig. 7. The changes in $\mathrm{Ca}^{2+}$ level in cytoplasm (A) and endoplasmic reticulum (B) of resting and ADP-activated platelets that were monitored using FURA-2 and Mag-Fluo-4, respectively, in the presence of TBS (control, green trace), thiacalix[4]arene C-145S (red) and calix[4]arene C-145 (blue). Typical results of three independent experiments

press clot lysis at concentrations, that were previously selected for in vivo application.

Platelet aggregation and $\mathrm{Ca}^{2+}$ balance. ADPinduced platelet aggregation in platelet rich plasma in the presence of C-145 and C-145S was applied as a basic test of C-145 and C-145S action on platelet aggregation. It was demonstrated that neither C-145 nor $\mathrm{C}-145 \mathrm{~S}$ inhibited platelet aggregation in the studied range of concentrations (Fig. 6). Only application of ten-times higher concentrations of both compounds leaded to inhibition of the rate of platelet aggregation on $15 \%$ for C-145 and on $25 \%$ for C-145S (Fig. 5).

As far as $\mathrm{Ca}^{2+}$ signaling is a known target of calix[4]arenes action [20] we estimated the changes in $\mathrm{Ca}^{2+}$ level in cytosol and endoplasmatic reticulum of resting and ADP-stimulated platelets. It was shown that C-145S, but not C-145 induces changes of the $\mathrm{Ca}^{2+}$ level in cytosol of resting platelets and attenuates the $\mathrm{Ca}^{2+}$ influx after stimulation with ADP (Fig. 7, A).

Similarly, the $\mathrm{Ca}^{2+}$ efflux from endoplasmic reticulum of platelets activated by ADP was much decreased in the presence of C-145S ( $5 \pm 2 \%)$ in comparison to control $(25 \pm 4 \%)$ and even in comparison to $\mathrm{C}-145$ action $(21 \pm 5 \%)$.

Thus, it was demonstrated that C-145S attenuate $\mathrm{Ca}^{2+}$-signaling in platelets. $\mathrm{C}-145 \mathrm{~S}$ suppress the stimulated increase of $\mathrm{Ca}^{2+}$ in cytosol and $\mathrm{Ca}^{2+}$ efflux from endoplasmic reticulum, thus inhibiting platelet reactivity. We detected only small tendency of inhibiting of $\mathrm{Ca}^{2+}$ efflux from endoplasmic reticulum of platelets by $\mathrm{C}-145$. However we assume that effects on $\mathrm{Ca}^{2+}$-signaling could be an explanation of inhibiting effect of C-145 on platelet reactivity in vivo.

Proliferation of endothelial cells. Study of endothelial cells proliferation in the presence of thiacalix[4]arene C-145S and calix[4]arene C-145 demonstrated the valuable increasing of cells number in experimental samples. Previously shown proliferation-stimulated effect of C-145 was confirmed. As for C-145S, it has had even more prominent stimulating action of cells proliferation (Fig. 8). Thus, $100 \mu \mathrm{M}$ of C-145 increased cell proliferation in 1.2

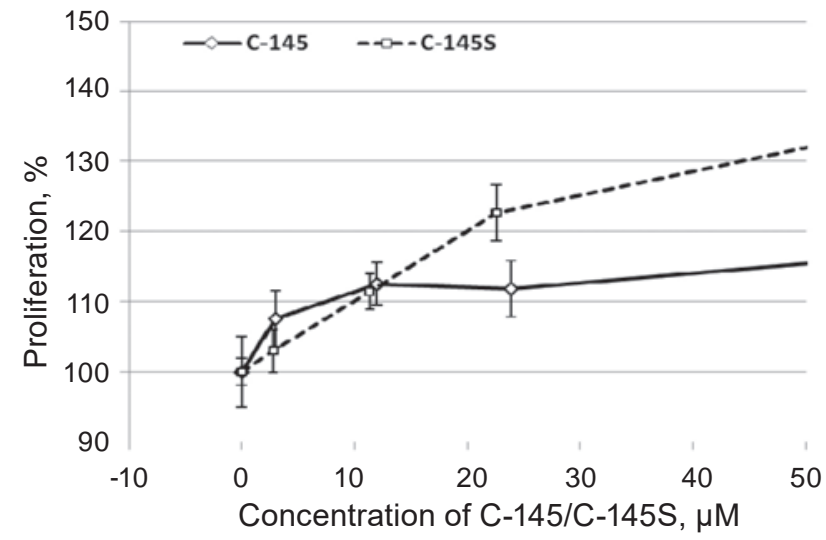

Fig. 8. Proliferation activity of endothelial cells (PAE cell line) in the presence of thiacalix[4]arene $C-145 S$ and calix[4]arene C-145 according to the results of MTT-test. Data are presented in percents from control meanings (probes without studied compounds, $100 \%$ ) 
$\boldsymbol{A}$

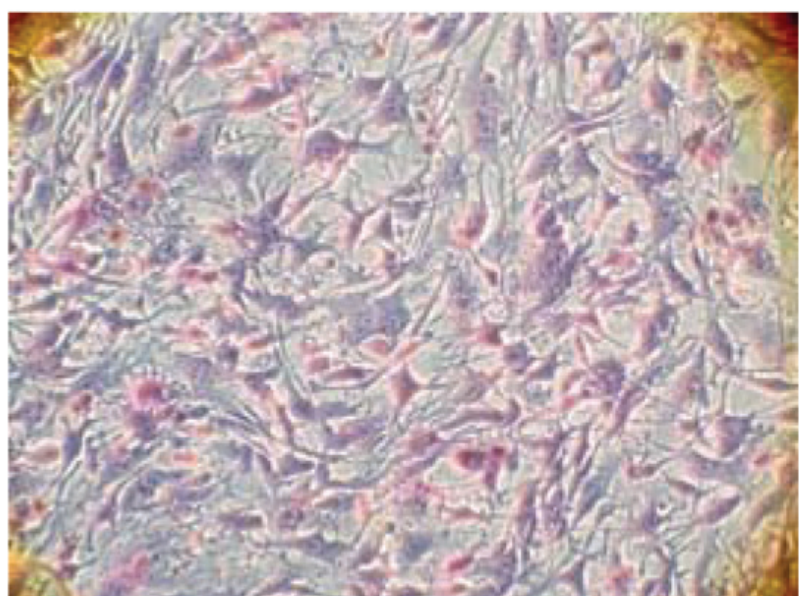

B

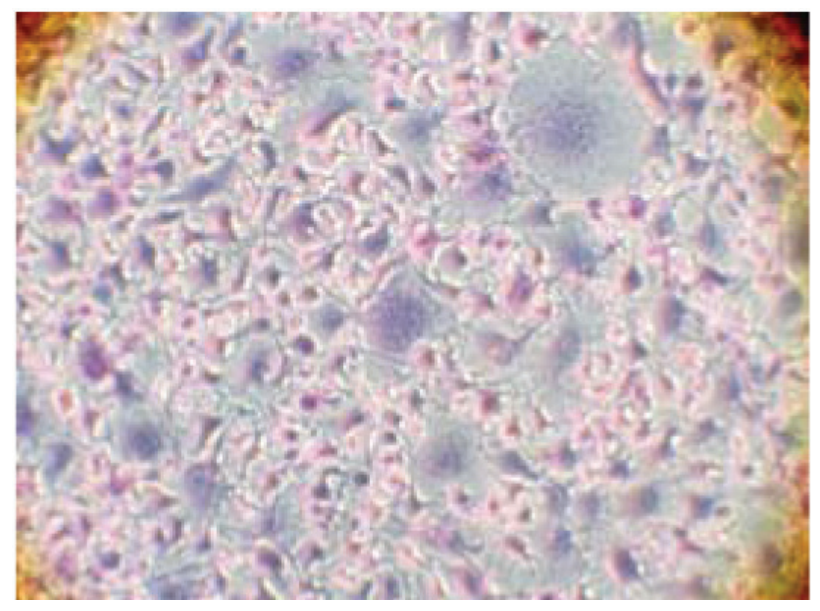

C

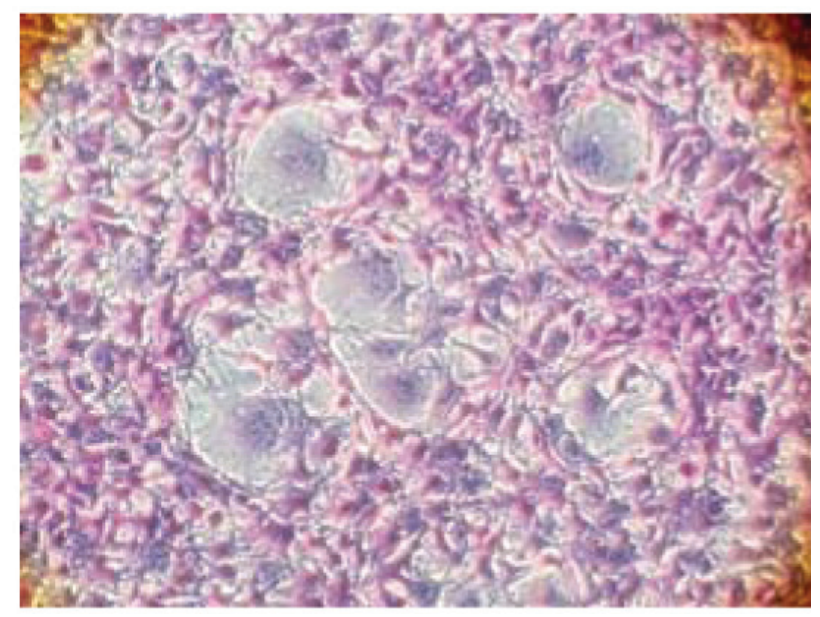

Fig. 9. Formation of capillary-like structures during the cultivation of endothelial cells PAE in the presence of thiacalix[4]arene C-145S (C) and calix[4]arene C-145 (B). Control cells are shown in panel $\boldsymbol{A}$ times, the same concentration of C-145S stimulated it in 1.5 times.

The morphology of cells that were cultivated in the presence of C-145 and C-145S was peculiar. We observed the formation of tube-like structures that were not detected in control probes and the total number of cells was not decreased in comparison to control sample (Fig. 9).

In conclusion, calix[4] arene C-145S was shown to be more potent inhibitor of fibrin polymerization then C-145, that was previously selected as anticoagulant. However, C-145S had much more outlined inhibitory action on $\mathrm{Ca}^{2+}$-signaling in platelets and endothelial cells proliferation.

Acknowledgement. The research was a part of Project N64 "Study of calix[4]arenes as haemostatic, antifibrinolytic and antithrombotic agents" according to targeted complex program of NAS of Ukraine for fundamental research "Fundamental issues of new nanomaterials and nanotechnologies creation".

\section{ДІЯ КАЛІКС[4]АРЕН- МЕТИЛЕНБІСФОСФОНОВОЇ КИСЛОТИ С-145 ТА ÏÏ СІРКОВМІСНОГО АНАЛОГА HА ГЕМОСТАЗ}
B. О. Чернишенко ${ }^{1 \bowtie}$, О. В. Савчук ${ }^{1}$, С. О. Черенок², О. М. Силенко ${ }^{2}$, А. О. Негеля ${ }^{3}$, Л. О. Касаткіна ${ }^{1}$, Л. В. Пирогова ${ }^{1}$, В. А. Дідківський ${ }^{1}$ О. І. Юсова ${ }^{1}$, В. І. Кальченко ${ }^{2}$, Л. В. Гарманчук ${ }^{3}$, Т. В. Гриненко, Е. В. Луговськой
${ }^{1}$ Інститут біохімії ім. О. В. Палладіна НАН України, Київ;

${ }^{2}$ Інститут органічної хімії НАН України, Київ;

${ }^{3} \mathrm{HНЦ} \mathrm{«Інститут} \mathrm{біології} \mathrm{та} \mathrm{медицини»,}$

Київський національний університет імені Тараса Шевченка, Україна;

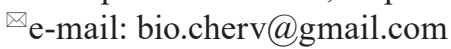

C-145 (октанатрієва сіль калікс[4]арен-тетра-метиленбісфосфонової кислоти) було раніше обрано як специфічний антикоагулянтний агент, який пригнічує полімеризацію фібрину, не маючи відчутного впливу на інші параметри системи зсідання крові. Оскільки C-145S (октанатрієва сіль калікс[тіа-4]арен-тетра-метиленбісфосфонової кислоти) має більшу гідрофобну 
чашу, можна очікувати його більшу антиполімеризаційну активність порівняно із C-145. Метою цієї роботи було порівняння дії обох органічних сполук на полімеризацію фібрину, фібриноліз, агрегацію тромбоцитів та проліферацію ендотеліоцитів. Полімеризацію фібринового згустку в плазмі крові за дії АЧТЧ-реагенту та гідроліз фібринового згустку за дії тканинного активатора плазміногену в присутності C-145 та C-145S вивчали за допомогою турбідиметричного аналізу. Ефект C-145 та C-145S на активацію Glu-плазміногену стрептокіназою визначали за допомогою хромогенного субстрату S2251, a агрегацію тромбоцитів - за допомогою агрегатометрії. Стимульований викид $\mathrm{Ca}^{2+} 3$ ендоплазматичного ретикулума та цитоплазми вивчали за допомогою спектрофлуориметрії із застосуванням специфічних флуоресцентних зондів Mag-Fluo-4 та FURA-2. Як C-145, так і C-145S знижувала кінцеву мутність згустку і подовжувала час напівлізису згустку в плазмі крові людини. Однак у модельній системі 3 полімерним фібрином desAB C-145 виявився ефективнішим інгібітором фібринолізу. C-145S, але не C-145, індукував зміни концентрації $\mathrm{Ca}^{2+}$ в цитоплазмі тромбоцитів у стані спокою, а також вірогідно інгібував (на $30 \%$ ) викид $\mathrm{Ca}^{2+} 3$ ендоплазматичного ретикулума тромбоцитів, активованих ADP. Як C-145, так і C-145S стимулювали проліферацію ендотеліальних клітин свині (PAE). Таким чином, показано, що калікс[4]арен C-145S був ефективнішим інгібітором полімеризації фібрину порівняно з C-145, який раніше було обрано для створення антикоагулянтного агента. $\mathrm{C}-145 \mathrm{~S}$ також виявляв вираженіший інгібіторний ефект на кальцієвий сигналінг тромбоцитів i стимулюючий ефект на проліферацію ендотеліоцитів. Отже, С-145 виявився перспективнішою молекулярною платформою для створення антитромботичного агента.

К л ю ч о в і слов а: калікс[4]арен, гемостаз, фібриноліз, ендотеліоцити, тромбоцити, зсідання крові, антитромботичні препарати.

\section{ДЕЙСТВИЕ КАЛИКС[4]АРЕН- МЕТИЛЕНБИСФОСФОНОВОЙ КИСЛОТЫ С-145 И ЕЕ СЕРОСОДЕРЖАЩЕГО АНАЛОГА НА ГЕМОСТАЗ}

\author{
B. А. Чернышенко ${ }^{1 \bowtie}$, О. В. Савчук 1 , \\ С. А. Черенок², О. М. Силенко ${ }^{2}$, \\ А. А. Негеля ${ }^{3}$, Л. А. Касаткина \\ Л. В. Пирогова ${ }^{1}$, В. А. Дидкивский ${ }^{1}$, \\ Е. И. Юсова ${ }^{1}$ В. И. Кальченко ${ }^{2}$, \\ Л. В. Гарманчук ${ }^{3}$, Т. В. Гриненко ${ }^{1}$, \\ Э. В. Луговскойㄴ, С. В. Комисаренко
}
${ }^{1}$ Институт биохимии им. А. В. Палладина НАН Украины, Киев;
${ }^{2}$ Институт органической химии НАН Украины, Киев;
${ }^{3}$ УНЦ «Институт биологии и медицины», Киевский национальный университет имени Тараса Шевченко, Украина; 凶e-mail: bio.cherv@gmail.com

C-145 (октанатриевая соль каликс[4]арен-тетра-метиленбисфосфоновой кислоты) был ранее выбран в качестве специфического антикоагуляционного агента, угнетающего полимеризацию фибрина, не оказывая ощутимого воздействия на другие компоненты системы свертывания крови. Поскольку C-145S (октанатриевая соль каликс[тиа-4]арен-тетра-метиленбисфосфоновой кислоты) обладает большей гидрофобной чашей, можно ожидать его большую антиполимеризационную способность по сравнению с C-145. Целью данной работы было сравнение эффектов обоих органических соединений на полимеризацию фибрина, фибринолиз, агрегацию тромбоцитов и пролиферацию эндотелиоцитов. Полимеризацию фибринового сгустка в плазме крови под действием АЧТВ-реагента и гидролиз фибринового сгустка под действием тканевого активатора плазминогена в присутствии C-145 и $\mathrm{C}-145 \mathrm{~S}$ изучали с помощью турбидиметрического анализа. Эффект C-145 и C-145S на активацию Glu-плазминогена стрептокиназой определяли с помощью хромогенного субстрата S2251, a 
агрегацию тромбоцитов - с помощью агрегатометрии. Стимулированный выброс $\mathrm{Ca}^{2+}$ из эндоплазматического ретикулума и цитоплазмы изучали с помощью специфических флуоресцентных зондов Mag-Fluo-4 и FURA-2 методом спектрофлуориметрии.

Как C-145, так и C-145S снижала окончательную мутность сгустка и продлевала время полулизиса сгустка в плазме крови человека. Однако в модельной системе с полимерным фибрином desAB C-145 оказался более эффективным ингибитором фибринолиза. C-145S, но не C-145, индуцировал изменения концентрации $\mathrm{Ca}^{2+}$ в цитоплазме тромбоцитов в состоянии покоя, а также достоверно ингибировал (на $30 \%$ ) выброс $\mathrm{Ca}^{2+}$ из эндоплазматического ретикулума тромбоцитов, активированных ADP. Как C-145, так и C-145S стимулировал пролиферацию эндотелиоцитов свиньи (РАЕ). Таким образом, показано, что каликс[4]арен C-145S был более эффективным ингибитором полимеризации фибрина по сравнению с C-145, который ранее был выбран для создания антикоагулянтного агента. C-145S также имел более выраженный ингибиторный эффект на кальциевый сигналинг тромбоцитов и стимулирующий эффект на пролиферацию эндотелиоцитов. Итак, С-145 оказался более перспективной молекулярной платформой для создания антитромботического агента.

К л ю че в ы е с ло в а: каликс[4]арен, гемостаз, фибринолиз, эндотелиоциты, тромбоциты, свертывание крови, антитромботические препараты.

\section{References}

1. Gutsche CD. Calixarenes. An Introduction, Monographs in Supramolecular Chemistry. Royal Society of Chemistry, Cambridge. 2008, $276 \mathrm{p}$.

2. Vicens J, Harrowfield J. Calixarenes in the Nanoworld. Springer Verlag, Dordrecht. 2007, $354 \mathrm{p}$.

3. Kalchenko O, Cherenok O, Yushchenko $\mathrm{O}$, Kalchenko V. Complexation of calix[4]arenehydroxymethylphosphonic acids with amino acids. Binding constants determination of the complexes by HPLC method. J Incl Phenom. 2013; 76(1-2): 29-36.

4. Kalchenko VI, Kalchenko O, Cherenok S. Complexation of Calix[4]arene bis-hydro- xymethylenediphosphonic acid with amino acids. Binding constants determination by RP HPLC method. French-Ukr J Chem. 2015; 3(2): 93-100.

5. Baldini L, Casnati A, Sansone F, Ungaro R. Calixarene-based multivalent ligands. Chem Soc Rev. 2007; 36(2): 254-266.

6. Komisarenko SV, Kosterin SO, Lugovskoy EV, Kalchenko VI. Calixarene methylene bisphosphonic acids as promising effectors of biochemical processes. Ukr Biokhim Zhurn. 2013; 85(6): 106-128.

7. Bevza OV, Veklich TO, Shkrabak OA, Rodik RV, Kalchenko VI, Kosterin SO. The calix[4]arene C-107 is highly effective supramolecular inhibitor of the $\mathrm{Na}^{+}, \mathrm{K}^{+}$-ATPase of plasma membranes. Ukr Biokhim Zhurn. 2013; 85(2): 5-19. (In Ukrainian).

8. Lugovskoy EV, Gritsenko PG, Koshel TA, Koliesnik IO, Cherenok SO, Kalchenko OI, Kalchenko VI, Komisarenko SV. Calix[4]arene methylenebisphosphonic acids as inhibitors of fibrin polymerization. FEBS J. 2011; 278(8): 1244-1251.

9. Chernyshenko VO, Korolova DS, Dosenko VE, Pashevin DO, Kalchenko VI, Pirogova LV, Chernyshenko TM, Lugovska OE, Kravchenko NA, Makogonenko YM, Lugovskoy EV, Komisarenko SV. Calix[4]arene C-145 Effects on Plasma Haemostasis. Pharm Anal Acta. 2015; 6(8): 401-406.

10. Chernyshenko VO, Korolova DS, Nikolaienko TV, Dosenko VE, Pashevin DO, Kalchenko VI, Cherenok SO, Khranovska NN, Garmanchuk LV, Lugovskoy EV, Komisarenko SV. Calix[4]arene C-145 effects on cellular haemostasis. Biotechnologia Acta. 2016; 9(3): 37-43.

11. Chernyshenko V, Korolova D, Lugovska O, Dosenko V, Pashevin D, Kalchenko V, Nikolaenko T, Harmanchuk L, Lugovskoy E. Unexpected anti-platelet and promising proangiogenic effects of calix[4]arene C-145 in vivo. FEBS J. 2015: 282(Suppl. 1): 142.

12. Chernyshenko VO, Pirogova LV, Didkivskyi VA, Cherenok SO, Dosenko VE, Pashevin DO, Kalchenko VI, Makogonenko EM, Lugovskoy EV. Effects of Calix[4]arene C-145 on overall haemostatic potential of blood plasma in vitro and in vivo. $J$ Int Res Med Pharm Sci. 2016; 10(3): 146-151. 
13. Rublenko AM, Urvant LP, Makogonenko EM, Platonova TM, Tsap PIu, Chernyshenko TM, Kolesnikova IM, Fishchenko VO, Lugovskoy EV. Effect of protein $\mathrm{C}$ activator on overall haemostasis potential in donor and hip arthroplasty patient plasma. Ukr Biokhim Zhurn. 2011; 83(5): 32-39. (In Ukrainian).

14. Cattaneo M, Cerletti C, Harrison $P$, Hayward CP, Kenny D, Nugent D, Nurden P, Rao AK, Schmaier AH, Watson SP, Lussana F, Pugliano MT, Michelson AD. Recommendations for the Standardization of Light Transmission Aggregometry: A Consensus of the Working Party from the Platelet Physiology Subcommittee of SSC/ISTH. J Thromb Haemost. 2013; 11(6): 1183-1189.

15. Kasatkina LA. 4-Aminopyridine sequesters intracellular $\mathrm{Ca}(2+)$ which triggers exocytosis in excitable and non-excitable cells. Sci Rep. 2016; 6: 34749 .

16. Grynkiewicz G, Poenie M, Tsien RY. A new generation of $\mathrm{Ca}^{2+}$ indicators with greatly improved fluorescence properties. J Biol Chem. 1985; 260(6): 3440-3450.
17. Mosmann T. Rapid colorimetric assay for cellular growth and survival: application to proliferation and cytotoxic assayas. J Immunol Methods. 1983; 65(1-2): 55-63.

18. He S, Antovic A, Blombäck M. A simple and rapid laboratory method for determination of haemostasis potential in plasma. II. Modifications for use in routine laboratories and research work. Thromb Res. 2001; 103(5): 355361.

19. Ryan EA, Mockros LF, Weisel JW, Lorand L. Structural origins of fibrin clot rheology. Biophys J. 1999; 77(5): 2813-2826.

20. Veklich TA, Shkrabak AA, Slinchenko NN, Mazur II, Rodik RV, Boyko VI, Kalchenko VI, Kosterin SA. Calix[4]arene C-90 selectively inhibits $\mathrm{Ca}^{2+}, \mathrm{Mg}^{2+}$-ATPase of myometrium cell plasma membrane. Biochemistry (Mosc). 2014; 79(5): 417-424.

Received 13.07.2018 